\title{
IMPLEMENTATION AND ASSESSMENT OF AN EXPERIMENT IN REFLECTIVE THINKING TO ENRICH HIGHER EDUCATION STUDENTS' LEARNING THROUGH MEDIATED NARRATIVES
}

\begin{abstract}
This article describes an intervention aimed at fostering reflective thinking in order to investigate its impact in the learning process and competences development of two groups of second-year students on the Early Childhood Education Degree at the University of Barcelona. The design of the study was based on experimental parameters which we characterise here as quasi-experimental with a quasi-control group. The apparatuses used were narrative approaches as vehicles for reflection on students' own activities. A self-administered questionnaire (with closed and open written responses) assessed the effects of the intervention. The resulting data were analysed with triangulated statistical techniques (lexicometry and bivariate statistics). Our findings confirm that reflective thinking through narratives is valuable for the meaningful understanding of knowledge and its reinterpretation from the standpoint of students' self-regulation of their own learning.
\end{abstract}

\section{Keywords}

Higher education; reflexivity; pre-service teachers; skills development; learning; narratives

\section{Highlights}

- Monitoring the development of students' subjectivity is possible through narratives

- Narrative-reflective apparatuses help creating conflict and drive action

- Narrative-reflective thinking break students' belief systems and their representations

- Reflective thinking help raising awareness of what students learn and how

- Reflective thinking help linking knowledge with experience and go beyond

\section{Learning-centred teaching in higher education}

The approaches encouraged by the European Higher Education Area (EHEA) involve principles akin to those of 'learning-centred teaching' (Zabalza, 2000, p. 459), which confers a special significance on the title of Davies' monograph 'The Shift from teaching to learning' in the journal Higher Education in Europe (Davies, 1998). Towards the end of the $20^{\text {th }}$ century this journal was already registering a serious concern with the inadequacies of teaching approaches more suited to the demands of the disciplines and their programmes than to students' needs. This article is an addition to this line of work and argues for the benefits of a more pluralistic approach to the modes of teaching-learning in higher education. We centre our research particularly on methods which favour students' self-management of their own resources (in the sense of self-regulation, self-efficacy, autonomy and self-awareness), reflective thinking and awareness of how they construct their knowledge (Bird, 1997; Fabregat, Guardia, \& Forés, 2016; Ion, Silva, \& Cano, 2013; Medina, Jarauta, \& Imbernón, 2010; Pérez-Burriel, 2010; Tejada \& Ruiz, 2016). 
Among the different organisational and methodological options closest to this approach in university education (De Miguel, 2006; Wenger \& Fergunson, 2006) we chose two. The first was self-directed learning strategies (Bourner \& Flowers, 1997) based on the student's autonomous study and work (De Miguel, 2006). We grounded the choice of this approach in educational research (Parra, 2004; Sabariego, 2014) which shows that a learning environment can be created in which students learn through the research method, thus at the same time acquiring the skills necessary for both the production of knowledge and their own professional development (Cortés-Nieto, Londoño-Toro, Luna-de-Aliaga, Palacios-Sanabria, \& TorresVillareal, 2008). To this end three didactic methods were deployed (Parra, 2004, pp. 73-74): the inquiry-based approach, non-directivity and inductive teaching. Secondly we chose learning approaches from a narrative and (auto)biographical perspective (Alliaud \& Suárez, 2011; Suárez, 2011). Portfolios (Seldin, Miller, \& Seldin, 2010; Zubizarreta, 2009), reflective diaries (Cowan, 2014; McGarr \& Moody, 2010; Zabalza, 2004), stories of students' learning experiences, and digital narratives (Rodríguez \& Londoño, 2009) are approaches to autobiographical reconstruction which help learners to investigate, reconstruct, document and communicate the knowledge constructed through their experience of learning. Reflective writing enables students to learn about themselves, by themselves, and to include themselves in their own learning process (Contreras, 2011), thus helping knowing to merge with doing.

Narrative and reflective exploration, along with the responsibility and autonomy required by project- and problem-based methods, favour these reflective conditions (Schön, 1983). Narrative documentation enables us to create engaging learning situations and activities through apparatuses. Michel Foucault defines an apparatus in the following terms: ' $a$ thoroughly heterogeneous ensemble consisting of discourses, institutions, architectural forms, regulatory decisions, laws, administrative measures, scientific statements, philosophical, moral and philanthropic propositions-in short: the said as much as the unsaid. Such are the elements of the apparatus. The apparatus itself is the system of relations that can be established between these elements' (Foucault, cited in García Fanlo, 2011, p. 1). Narratives are potentially rich enough to produce knowledge which recuperates existence and transforms it into the content of what is to come. Narratives transform experience into content for learning, situating students in a reflective relationship towards their action and experience in the classroom. Writing about their experience of the learning process enables them to see themselves afresh, (re)think themselves, (re)incorporate themselves and (re)engage themselves in what they are experiencing, in what they are being taught and in what is being presented to them in class. Among the preconditions for this to take place are: (a) using an autobiographical view, from the standpoint of students' own experience, to promote thinking and have them respond to questions such as: What do the materials we're using have to do with my story? Have I experienced something related to them? What was the process like, how did it affect me? What can I take on now and learn from it?; (b) seeking the meaning of what is experienced in the classroom (and articulation of how it is experienced, felt and shared); and (c) exchanging experiences in groups in order to "think with" and "in the presence of" others in meaningful learning environments. Also, this enables us to develop reflective thought in the learning process (Fullana, Pallisera, Colomer, Fernández, \& Pérez, 2013; González-Moreno, 2012; Phan, 2008; Romero, 2007). Writing stories is a way for students to have access to their subjective experiences in order to take their own educational history, beliefs, prejudices, prior knowledge and schemes of action as objects of reflection. These are all key aspects of sustainable education (like competence-based learning) since they enable us to: (a) raise awareness of and make explicit what the learning achieved and how it was achieved; (b) 
interpret and understand the meaning of this; (c) write and rewrite reflectively; and (d) read individually and in groups with the ensuing benefits of exchange and feedback.

\subsection{Reflective thinking and developing competences}

In How we think the American philosopher John Dewey defines reflective thought as the 'active, persistent, and careful consideration of any belief or supposed form of knowledge in the light of the grounds that support it and the conclusion to which it tends' (1933, p. 9). It is thus a cognitive attitude which provides a foundation for action with a high level of originality, and through which a careful examination of the principles underlying reflective practice can be made (Romero, 2007).

Higher education has also been influenced by the reflective tradition in planning teaching and learning activities (Afshar \& Rahimi, 2016; Brockbank, McGill, \& Beech, 2002; Fullana et al., 2013; Poblete \& Villa, 2007). Reflective skills are important not only for their role in the acquisition of competences, but also for the reformulation of human knowledge, practice and experience (Fullana et al., 2013) for the purpose of acting and thinking professionally (Barton \& McCully, 2007; Holmes \& Clizbe, 1997; Mann, Gordon, \& MacLeod, 2009; National Academy of Sciences, 2005). In recent studies on Confucian-heritage cultures (CHCs) reflective thinking is focused also on moral and ethical factors (Fwu, Chen, Chih-Fen, \& Wang, 2018). As Anijovich et al. $(2009$, p. 44$)$ observe, 'behind the idea of training reflective professionals we find issues such as professionalization, its status and function; professional autonomy, its scope and possibilities for development; and the nature, development and range of teaching and research.'

The goal should be to show that the student increasingly masters the process through which s/he 'knows' something -finding reasons and criteria, making judgments about reality, taking better decisions, producing novel and original solutions in order to answer her/his questions and solve her/his problems. In this process various different stages or levels of reflective thought have been discerned (Bain, Ballantyne, Mills, \& Lester, 2002; Dewey, 1933; Grossman, 2008; Poblete \& Villa, 2007; Ryan, 2013). We coincide with the view that raising awareness is the basis for all transformative reflective action (Gaitán, 2007), its outcome in the last instance being the (re)incorporation of new qualities into the knowledge acquired and the skills that the learner is developing (Quintanar, 2001). In the words of González-Moreno (2012, p. 613), 'the activity of teaching involves making advances on the basis of an analytical and critical attitude which enables us to reconstruct experience in detail in order to learn.'

For in-depth and active learning to take place, academic and/or professional reflection in higher education requires critical thinking skills (Dwyer, Hogan, \& Stewart, 2014; Phan, 2008). This refers to a type of critical or transformational reflection (Ryan,2013) enabling individuals to go beyond simply retaining information towards gaining a more complex understanding of the information presented to them (Dwyer et al., 2014; Halpern, 2003). Critical reflection is not an intuitive skill and the development of reflective thinking should be fostered in appropriate educational settings, without taking it for granted (Ryan, 2013). This approach yields indicators which can orient the learning activity towards constant reflection on what is being learned, how it is being learned and how this is reconstructed: indicators for reflective skills (students becoming aware of what they are saying, doing and thinking) for raising awareness through reflective writing; indicators of aspects of thought (justifying, reasoning in order to regulate one's own learning process) for inquiry through debate and mediation; and indicators for 
critical and transformational thinking (demonstrating new ideas, taking decisions, projecting oneself into future teaching practice, etc.) for transformative reflection and the reconstruction of thought and learning. The teacher is indispensable in creating the educational environments necessary for awakening curiosity and fostering learners' autonomy during their own learning processes (Dewey, 1933; Medina et al., 2010). When students have the chance to examine and reflect on their beliefs, philosophies and practices, they are more likely to see themselves as active agents and lifelong learners in their academic and professional careers (Mezirow, 2006).

In line with Vygotsky's cultural-historical approach, in this study reflective thinking has a social origin and a mediated structure (Solovieva \& Quintanar, 2004; Talizina, 2009) supported in its functioning by external and internal media. Teaching and learning activities which seek to develop reflective thinking should aim to build the conditions for the subject to be aware of what $s /$ he says and does. For this purpose the choice of tasks and the strategy and orientation they require when put into practice should involve conscious design and deliberate organization. Even more important is that students should be clear about the objectives and the meaning of what they are to do. It is not possible to discuss, make judgments, take decisions or make progress in the cognitive self-regulation of learning activities without knowing the how or the why. Thus a pedagogical approach with these purposes responds to what is known as Activity Theory (González-Moreno, 2012; Talizina, 2009). In order to promote educational self-regulation and give rise to reflective thinking, teaching and learning activities should fulfil the following conditions, combined with guidance and systematization:

1. Identifying the actions included in the different types of cognitive activities and being aware of the structure of their own training, with its component parts, functions, basic characteristics and regularity.

2. Stimulating students' cognitive interest, motivating and guiding activities and providing constant feedback.

3. Maintaining stability, responsibility and organisation in educational actions in order to promote learning processes and the activation of cognitive schemata to organize and reorganize current knowledge and provide a framework for future understanding.

4. Fostering communication between teachers and students and an appropriate classroom environment.

5. Showing mastery of the subject and materials.

In the light of these considerations, the teaching and learning activities in this study were conceived as social and emotional experiments in fostering students' mediation with themselves and others, and as forms of communicative exchange within the classroom aimed at having students examine and reflect on their own beliefs, prior knowledge and practice. The design of the activities incorporated orientation and systematization (Talizina, 2009), and in order to develop thinking skills and their component competences (concepts, representations, mental actions) we incorporated González-Moreno's (2012) quality recommendations: permanent feedback in environments of trust; student-led tasks stimulating self-regulation; clear instructions on what to do, how to proceed and the conditions required; and the provision of support for introspection, group reflection and the sustainability of students' emotional process.

Grounded in these principles, this article presents an experiment, over a single module, in facilitating reflective thinking and students' awareness in the design of an innovation based on an observation process in real contexts, using autobiographical methods. We agree with the literature that experiments of this type give value to the context, the teachers and the 
apparatuses for developing students' reflective thinking (Hmelo-Silver, 2004; Hua, 2008; Koszalka, Song, \& Grabowski, 2002; Yuen Lie Lim, 2011). When organising and planning a student-centred teaching-learning process it is also advisable to foster learners' awareness of the cognitive, emotional and relational dimensions of learning; and finally to plan carefully staged processes of self-monitoring so that students can progressively master the regulation of their own learning (De Miguel, 2006).

\section{Methodology}

During the 2014-15 academic year it was decided to take on the challenges outlined above using approaches with instruments from educational research and the narrative/ (auto)biographical approach. Thus the purpose of this paper is to present the effects of an experiment in reflective thinking through mediated narratives on pre-service teachers' learning process and competences development. This experiment was implemented on a compulsory module in the second year of the Bachelor's degree programme in Early Childhood Education in the Faculty of Education, University of Barcelona. Within the course curriculum, the experiment was carried out in the 6 ECTS module "Observation and Innovation in the School Classroom". Since 2011 the teaching staff of this module have been investigating what modifications or changes should be made in order to improve students' learning and development of competences (Sabariego, 2014).

Thus, we designed and implemented an embedded quasi-experimental study (Plano Clark \& Creswell, 2008) within a two-phase Project-Oriented Learning (De Miguel, 2006) sequence. The first phase included the design and implementation of the intervention; herein the apparatuses used were narrative approaches as vehicles for reflection on students' own activities. The second phase comprised the quasi-experimental study (Campbell \& Stanley, 1966; White \& Sabarwal, 2014) assessing the effects of the intervention. Both phases are described below.

During the fieldwork, ethical considerations regarding the confidentiality of data were addressed according to the Code of Good Research Practices (Universitat de Barcelona, 2010). Students were briefed on the study and its ethical implications during teaching sessions, before completing the tasks and questionnaires in their classrooms.

\subsection{First phase: intervention design and implementation}

We decided on a method based on the experiential and reflective learning of the theoretical foundations (definition and modalities of observation in primary education), methodologies (planning of an observation process) and instruments (hands-on management of information recording and analysis techniques) presented in class in order to put students in the place of real observers of reality and thereby foster self-learning and the self-management of knowledge. This meant, in short, that students would learn to observe through directly managing their own observation processes: by planning the observation guide; recording, analysing and interpreting data; reformulating the outcomes as a plan for educational innovation; and finally narrating the reflective process followed, i.e. how they produced knowledge around the concept, development and usefulness of educational innovation in the practice of primary school teaching. Autobiographical and narrative methods were introduced at three specific times during the course, and the apparatus was designed around this schedule (Figure 1): 
1: Writing a narrative on the value and concept of innovation, drawing on students' own experience of innovation throughout their education.

This first task was introduced at the beginning of the module, when we look at the importance of observation in educational processes aimed at innovation. We wished students to reflect on the meaning, value and concept of innovation in primary education, and to do this on the basis of their own experience. This reflective task was set out for them in a mediated form, firstly by themselves (individually) and then with their classmates (collectively), such that they could build and rebuild it in the classroom. To this end we asked them to write two stories: (a) an initial individual one, involving a period of reflective writing from their own experience; and (b) a further individual narrative undertaken after the group work.

2: Reading an account of good practice in primary education innovation, and making a critical commentary of it.

The second task was initiated when students were analysing the data from their observations. At this time we also presented them with the contents of the article they were to write in their groups and where they were to show their results (this was the assessed task with most weight in the module). In one of the sections of the article they were required to propose an innovation in the scenario that they had observed. Experience shows that this section lacks sufficient depth and guidance to make comparison of the different groups' assignments possible. Students needed more input on the concept and systematization of an educational innovation process in order for them to complete the assignment more fully. Thus we argued that in this module more space should be allotted to enable them to integrate theory and practice on the basis of two meaningful texts. Once again this task was an individual reflection mediated firstly by students' reading and secondly by interaction with their classmates (in groups); and again they were asked to write two narratives answering three questions: (1) What do these texts say? (2) What do they mean to you? (3) What would you say about them?

3: Production of a digital narrative (Rodríguez \& Londoño, 2009), in which reflection on the value of innovation in students' future professional lives was encouraged.

The third and last task was introduced when students were working on the article and preparing the digital narrative to present their learning process. They were given specific instructions on how to write (1) the section of the article concerning the innovation proposal, and (2) the contents of the digital narrative. The rubric for the article was: "As a result of our observations we can put forward proposals for improving the activities observed. (1) What importance, in your view, does this idea have in the context of the work you're doing? (2) What specific innovation would you suggest to improve the activities you've observed?" Also, when the digital narrative was presented, reflection on the value of innovation in students' future teaching practice was encouraged by instructions such as: "Do you think you will innovate when you are working as teachers?"

The aim was for them to become aware of and to discuss in their groups what uses innovation had in improving educational practice. One again the task was a mediated reflection, and they were asked for two narratives: a written narrative for the section of the article with an innovation proposal, and a group oral product on their view of innovation as a key feature of primary school teachers' professional practice. 


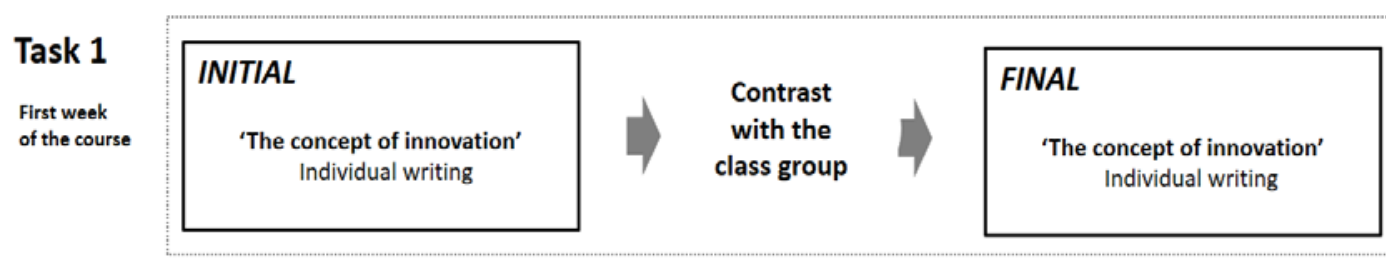

Task 2

First

observations

in the course
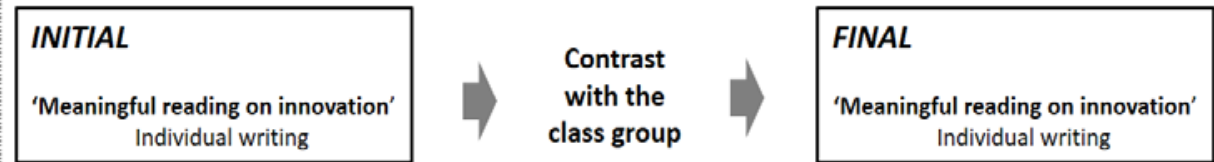

Task 3

Last week

of the course
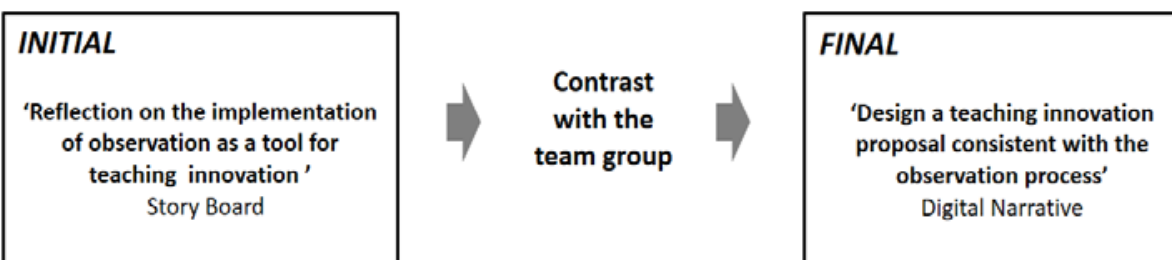

Figure. Schedule of the reflective thinking apparatuses on the 'Classroom Observation and Innovation' module. Source: created by the authors

\subsection{Second phase: an embedded quasi-experimental study}

In order to determine the impacts of this experiment, we carried out an embedded research study with a quasi-experimental design (Campbell \& Stanley, 1966; White \& Sabarwal, 2014), featuring a quasicontrol group. We used a self-administered questionnaire (with open textual questions and closed questions featuring 7-point Likert scales) to identify and assess (a) the effects of the tasks for promoting reflective thinking, and (b) the students' satisfaction with these, from their own perspective.

The questionnaire was designed to enquire into the impact of innovations in the Project-Oriented Learning sequence. Specifically, the objective of the instrument was to determine students' opinions on and evaluation of the learning strategies used and to yield proposals for optimizing the development of competences. In line with the study by Fullana, Pallisera and Colomer (2013), the questionnaire featured six scales, each linked to a theoretical dimension of the development of reflective thinking: (I) incorporation of RT in the learning process, (II) perception and awareness of one's own learning process, (III) connections between experience and knowledge, (IV) reflective self-awareness and self-regulation, (V) assessment of methodologies and proposals for improvement, and (VI) satisfaction with the experience. The questionnaire scales revealed values which can be regarded as satisfactory in terms of the reliability of the items measured by Cronbach's alpha of internal consistency (although questions 1 and 7 had low reliability). The present article only presents results from the following dimensions:

a. overall satisfaction (dimension $\mathrm{VI}$, represented by question 8: 'Please score from 1 to 10 the degree of overall satisfaction you gained from completing these tasks').

b. the incorporation of RT in the learning process, in order to evaluate: (a) students' feelings about the tasks they had to complete (dimension I, represented by question 1: 'When they told me about the tasks I felt...' (Cronbach's $\alpha=.652$ ) and question 2: 'Why did you feel that way?') and 
(b) usefulness, based on more personal consequences (dimension I, represented by question 3: 'I think that the tasks we had to do enabled me to...' (Cronbach's $\alpha=. .874$ ) from the students' own point of view.

The questionnaire was administered to two groups on the module: one which had followed the process described above and the other which had only undertaken the same teaching research assignment as the other groups on the module. The students were assigned to the two groups (experimental and control) at random, in order of their enrolment in the course. Thus the groups were already formed before classes began.

Below we present the outcomes from each dimension, showing firstly the descriptive values of the two contrasting groups, 'experimental' (32 students) and 'control' (42 students). Subsequently we detail the statistically significant differences (using Fisher's Student's- $t$ test and calculating the magnitude of the effect using Cohen's $d$ ) (Table 1). We used the IBM program SPSS Statistics 19.0 to process the data. Lastly, we triangulated the written information from the 'learners' feelings' dimension using two text analysis programs, DTM_Vic v5.7 and Iramuteq v07.

\section{Results}

The results reported below integrate the quantitative and qualitative data of the questionnaire in relation to the second phase. The results are presented by question, starting with dimension $\mathrm{VI}$, represented by question 8 , and followed by dimension I, represented by questions 1,2 and 3 .

The Likert-type scale item (Question 8), which aimed to determine whether there was any significant relationships among the overall assessments of the modules made by the students from the two groups, showed no statistically significant differences in this dimension. The overall assessments made by the students were very similar (mean value 7 on a scale of 10). However, Table 1 shows, the responses to the individual items on incorporating RT in the learning process demonstrate that all the mean scores of the experimental group were higher. 


\begin{tabular}{|c|c|c|c|c|c|c|c|}
\hline \multirow[t]{2}{*}{ Dimensions } & \multirow{2}{*}{\multicolumn{2}{|c|}{ № and type of questions }} & \multirow[t]{2}{*}{ Items } & \multicolumn{2}{|c|}{$\begin{array}{l}\text { Experimental } \\
\text { Group }(n=32)\end{array}$} & \multicolumn{2}{|c|}{$\begin{array}{l}\text { Control Group } \\
(n=42)\end{array}$} \\
\hline & & & & Mean & SD & Mean & SD \\
\hline \multirow{17}{*}{$\begin{array}{l}\text { Incorporation of } \\
\text { RT in the } \\
\text { learning process }\end{array}$} & \multirow{7}{*}{$\begin{array}{l}\text { Question } \\
1\end{array}$} & \multirow{7}{*}{$\begin{array}{l}8 \text { Likert-scale } \\
\text { items with } 7 \\
\text { points }\end{array}$} & Doubts & 5.19 & 1.28 & 4.48 & 1.33 \\
\hline & & & Curiosity & 5.09 & 1.02 & 4.17 & 1.34 \\
\hline & & & Anxiety & 4.03 & 1.80 & 3.93 & 1.84 \\
\hline & & & Insecurity & 3.81 & 1.83 & 2.93 & 1.27 \\
\hline & & & Motivation & 4.16 & 1.22 & 4.07 & 1.27 \\
\hline & & & Learning challenge & 4.78 & 1.53 & 4.57 & 1.12 \\
\hline & & & Conflict & 4.16 & 1.78 & 3.10 & 1.65 \\
\hline & $\begin{array}{l}\text { Question } \\
2\end{array}$ & Open-textual & - & - & - & - & - \\
\hline & \multirow{9}{*}{$\begin{array}{l}\text { Question } \\
3\end{array}$} & \multirow{9}{*}{$\begin{array}{l}8 \text { Likert-scale } \\
\text { items with } 7 \\
\text { points }\end{array}$} & Reflect on innovation & 5.78 & 1.09 & 4.88 & 1.19 \\
\hline & & & Learning innovation & 5.47 & 1.07 & 4.88 & 1.19 \\
\hline & & & Become aware of difficulties & 5.59 & 1.16 & 4.71 & 1.23 \\
\hline & & & $\begin{array}{l}\text { Awareness of strengths and } \\
\text { skills }\end{array}$ & 5.81 & 1.04 & 4.62 & 1.20 \\
\hline & & & Realize that I have to improve & 5.59 & 1.34 & 4.76 & 1.20 \\
\hline & & & $\begin{array}{l}\text { Understanding practical } \\
\text { complexity }\end{array}$ & 6.19 & 1.06 & 5.60 & 1.08 \\
\hline & & & Give value to stories & 5.53 & 1.29 & 4.71 & 1.33 \\
\hline & & & Position myself & 5.72 & 1.08 & 4.71 & 1.25 \\
\hline & & & $\begin{array}{l}\text { Awareness of learning } \\
\text { process }\end{array}$ & 5.56 & 1.04 & 4.90 & 1.10 \\
\hline $\begin{array}{l}\text { Satisfaction } \\
\text { with the } \\
\text { experience }\end{array}$ & $\begin{array}{l}\text { Question } \\
8\end{array}$ & $\begin{array}{l}1 \text { Likert-scale } \\
\text { item with } 10 \\
\text { points }\end{array}$ & - & 7.16 & 1.22 & 7 & .98 \\
\hline
\end{tabular}

Table 1. Descriptive statistics of the quantitative data of the dimensions of the questionnaire. Source: created by the author

When we turn to the dimension of students' feelings about the tasks (Question 1), we see that the experimental group gave higher scores in all areas (Figure 2). Despite this, we only found statistically significant differences in the questions referring to doubts $\left(t_{(72)}=2,316 ; p=0,023\right.$; $d=1)$, curiosity $\left(t_{(72)}=3,366 ; p=0,002 ; d=1\right)$, insecurity $\left(t_{(72)}=2,440 ; p=0,017 ; d=1\right)$ and conflict $\left(t_{(72)}=2,440 ; p=0,010 ; d=1\right)$. These significant differences are consistent with the need to cause an emotional response (doubt or confusion) to develop reflective thinking (Dewey 1933; Schön, 1983; Perrenoud, 2004) and reflection in the learning process (González-Moreno, 2012; Nocetti \& Medina, 2018): if doubt (caused by the gap between what is expected and what is experienced - in our case, what the apparatuses required) is not aroused, there can be no conflict or instability, and therefore it is less likely that a reflective response will be given.

Figure. Mean scores on the scale 'When they told me about the tasks I felt...'

If we analyse by groups the reasons (Question 2) behind the feelings revealed by the above question, we can see the differences (in Table 2) in the terms of the most typical answers given by each group.

QUESTION 2:

'Why did you feel that way?' (referring to your answer to the question on the required tasks).

\begin{tabular}{l|l} 
Experimental group & Control group
\end{tabular} 
1) In general they were complex texts and I'm not used to having to analyse texts section by section.

2) Especially with the final assignment. At the beginning it looked dense and difficult, but as I was working on it I found the answers to my own questions. Tasks 1 and 2 were interesting and not very difficult.

3) When I don't know the challenge that something represents I always feel motivated and interested. It doesn't produce insecurity in me because I don't judge myself with the marks in mind.

4) The tasks seemed really open to me and that's why they raised questions. Also this was a learning challenge, which made me feel motivated and sure of myself.
1) Because it was a lot of work on top of the other assignments and the finals.

2) Because I had never done it.

3) Because I didn't know what the objective of the task was or now complex it was.

4) I felt that way because I didn't know how complex the task was.

Table 2. Typical texts from the two groups (analysed using DTM-Vic).

The control group's feelings centred on the added work, their lack of knowledge and the complexity of the task, while the experimental group based their assessments on the cognitive features of the tasks which raised questions due to the activities' poor organization or their complexity, which in turn aroused greater motivation and the desire to overcome the challenge. Although we used DTM-VIC for this analysis, we also decided to analyse the same question for each group with Iramuteq. Figure 3 shows the word-clouds obtained from the count of words used by students for the reasons behind their feelings. The lexical differences stem from the fact that the experimental group used more words related to their learning from the tasks: learn, reflect, understand, etc., all of which were linked to the assignment. In contrast, in the control group the work involved in carrying out the innovation tasks (i.e. the reading) was highlighted.

Figure. Word-cloud according to groups for 'Why did you feel that way?'

Examining the lexis of this question in more depth, Iramuteq provided an analysis of the similarity between words, displaying the lexical relationships for each of the two groups (Figure 4). The group with the reflective elements incorporated into their teaching apparatus presented a clear diversification of elements, mostly referring to their own learning process (for example the relationship of similarity between the words more and question; this can also be seen in the words grouped around doing, in which items such as insecurity, motivation and reflection appear). The control group, for which the teaching apparatus consisted of educational research only, presented a much more concentric and radial lexical field where the entire lexical set was based around work. Also, for this group we can see that the lexical ensemble mostly referred to the module's assessed assignments and their practical consequences (task, anxiety, time, difficult). These outcomes suggest that the experimental group seem to have centred more on themselves, while the control group focused more on the required task. 


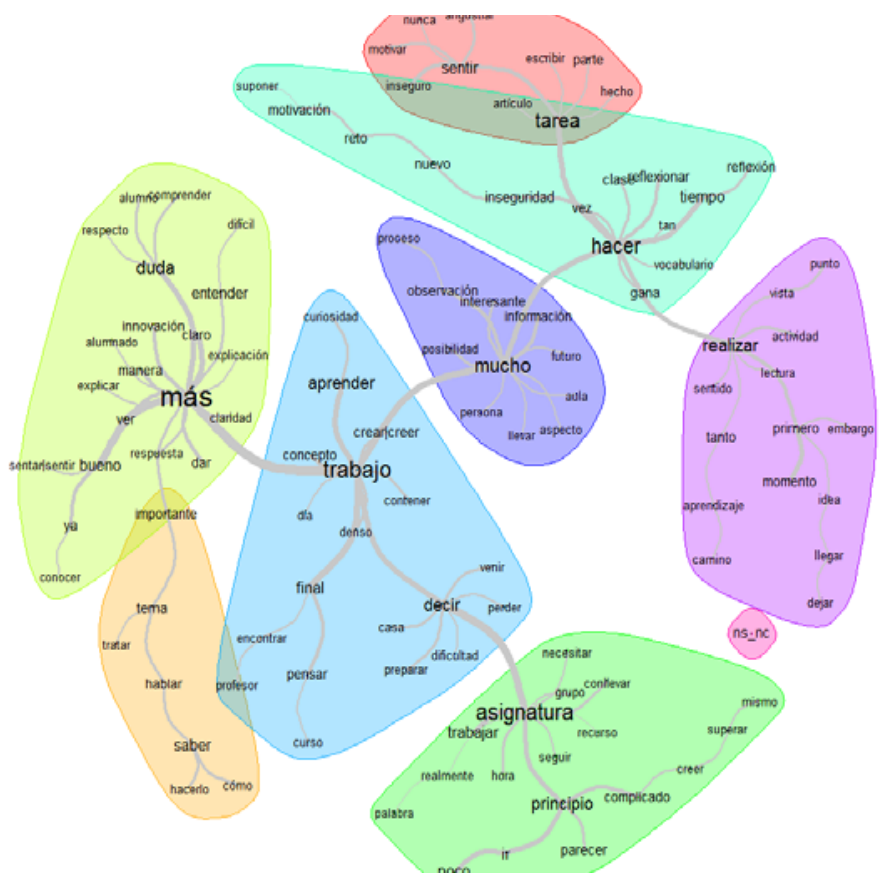

Experimental Group

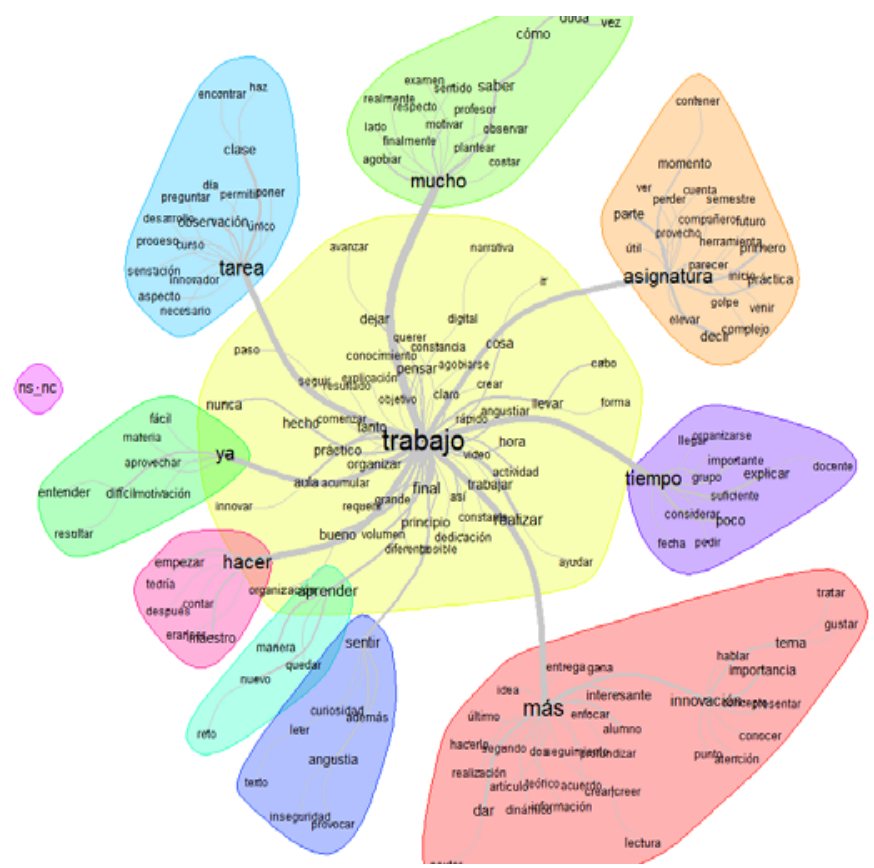

Control Group

Figure 4. Similarity analysis for the two groups. 
Lastly, in the following figure (Figure 5) we show the usefulness attributed by the students to the tasks (Question 3). The experimental group scored this more highly than the control group in all aspects. Also we found statistically significant differences in the following items: reflecting on innovation from experience (remembering experiences from school or their current studies) $\left(t_{(72)}=3,325 ; p=0,001 ; d=1\right)$; learning about innovation on the basis of experience $\left(t_{(72)}=2,188\right.$; $\mathrm{p}=0,032 ; \mathrm{d}=1)$; becoming aware of my difficulties in the learning process on innovation $\left(t_{(72)}=3,114 ; p=0,003 ; d=1\right)$; becoming aware of my strengths and skills in the process of learning about innovation $\left(\mathrm{t}_{(72)}=4,388 ; \mathrm{p}=0,000 ; \mathrm{d}=1\right)$; realising that I need to improve personally, professionally and/or as a student $\left(t_{(72)}=2,801 ; p=0,007 ; d=1\right)$; understanding the complexity of my future professional practice $\left(\mathrm{t}_{(72)}=2,351 ; \mathrm{p}=0,021 ; \mathrm{d}=1\right)$; giving value to narrative (both oral and written) to communicate and express myself $\left(t_{(72)}=2,647 ; p=0,010 ; d=1\right) ;$ positioning myself towards my reading and others' points of view on innovation $\left(t_{(72)}=3,614 ; p=0,001 ; d=1\right)$; and being aware of the learning achieved on innovation through narrative $\left(t_{(72)}=2,603 ; p=0,011\right.$; $\mathrm{d}=1)$.

Figure 5. I think that the tasks enabled me to ...

These data suggest that narrative strategies help students to adopt a reflective relationship with the activities in their learning process and help them to be more aware of what they learn and how. Our study shows that the tasks undertaken in the experimental group were useful for them mainly in linking experience to knowledge, and particularly in achieving a wider and more meaningful understanding of their field, both in theoretical and practical-professional terms. Also our findings confirmed that narrative apparatuses seem to foster self-reflection in the learning process, making students more aware of the process they went through and their own strengths and skills in relation to it.

\section{Discussion}

As seen above, the results revealed that the two groups' overall assessment of the module had almost identical mean values. Both groups, then, finished the module with high levels of satisfaction; however it was the experimental group which gave the highest scores to all the factors relating to the value of reflective thinking in their learning process (the dimensions of feelings and usefulness, as figures 2 and 5 have shown), focusing less on the work required, as was the case for the control group. These findings are in line with the results of others such as Mann, Gordon, and MacLeod (2009) who also reveal the paramount role of reflective practices integrated into the learning process in higher education. The combined quantitative and qualitative data provide insight into the students' perspectives on the learning process and impact of the incorporation of RT through mediated narratives. Reflective writing as the core learning activity enabled the meaningful reformulation of the learning acquired, integrating thought and action and linking the activities and contents treated in class to other meaningful areas. These findings correspond to those of Talizina (2009), who states that the educational outcome is, above all, the shaping of different types of cognitive activity or their elements: concepts, representations and mental actions. Likewise, they confirm the theses of González-Moreno (2012) and Solovieva and Quintanar (2004), according to whom a reflective learning process requires students to go through three basic procedures: (a) considering their own behaviour (how they learn); (b) becoming aware of what they are learning; and (c) regulating their own learning process. Triangulation with the lexicometry analyses revealed that the experimental group had a greater level of awareness of their learning than the group control.

Our findings also indicate that when students tackled apparatuses requiring them to reflect, their perceptions centred on the experiential consequences. From this, then, we may infer that all situated 
and meaningful learning requires elements which, above all, raise questions, so that students may then experience instabilities (Nocetti \& Medina, 2018) which trigger reflection. Recent research shows that teachers who reflect learn from their own experience and that this knowledge improves their professional practice (Avalos, 2007; Korthagen, 2010). Thus it seems certain that in the preparation of the narrative-reflective apparatuses we find differences with regard to other approaches to the teachinglearning process in the area of two broad dimensions: the creation of conflict (this is more physiological) and what drives action, i.e. curiosity aroused through questioning. Further, we would go as far as to affirm that this type of apparatus enables us to break students' belief systems and their representations of the mastery of knowledge or the subject, and from that point to offer them the opportunity to rebuild their own representations. This relationship between thinking and feeling is consistent with the flow of changing moods and emotions described by Newton (2013) as tasks progress, and accommodates individual thinking. In Shön's words (1983), the activities of teaching and learning provide theoretical, methodological and practical tools for reflecting while doing and on what is done, with the purpose of becoming more aware of this process and, in this way, transforming it.

\section{Conclusions and implications}

This study contributes by advancing the discussion regarding the role played by the apparatus, as a powerful mechanism of social construction composed of a multitude of both physical and cultural artefacts and components acting on different levels of interaction. In itself, an apparatus is something with a much broader reach than a teaching approach, merging the various areas and elements making up the university, the module and the classroom and beyond. Thus in higher education we should pay particular attention to how we make use of this type of cultural tool and the prevailing social dynamics in order to redirect them carefully towards the inscription of specific aspects of students' subjectivity. Therefore systematic modulation through inductive teaching (Bourner \& Flowers, 1997) and ongoing tutoring with teaching methods such as inquiry methodology (Parra, 2004), added to specific narrative tasks (Alliaud \& Suárez, 2011; Suárez, 2011), all enable us to monitor the development of changes in students' subjectivity; and we can understand this set of educational strategies as the specific active elements in a small part of the apparatus made manifest in the classroom.

From the perspective of teaching, the objective is to choose the necessary action and organise its execution in such a way that the shaping of knowledge and skills with the required quality is guaranteed (Talizina, 2009). Students, for their part, are faced with the compelling need to respond to this context, reconstructing the interpretative framework of their own educational career in order to bring meaning to the various tasks they have to do. In other words, the teacher's task is to provide a set of discursive conditions, through the instructions given, which are aimed at engendering specific practices. These represent a kind of high-performance mirror, so to speak, in which students can clearly see an in-depth reflection of their own educational activities, which are mainly oriented towards the concepts they have of themselves, of their professional practice and of the ways in which both of these are contextualized in the wider cultural field.

The teacher's task, then, goes beyond simply setting apparatuses in motion: it requires us to create certain conditions, contexts which bring reflection into play and lead to self-regulation of learning (Boekaerts \& Cascallar, 2006; Martínez Fernández, 2002). From this point of view the idea of the thinking culture is also useful. This relatively recently developed approach argues for "a classroom atmosphere in which various forces (language, values, expectations and habits) work together to articulate and strengthen good thinking" (Tishman, Perkins, \& Jay, 2006). Various different cultural forces have been identified at work in this educational transformation (Ritchhart, Church, \& Morrison, 2011; Ron Ritchhart, 2015); forces which, in 
various ways, have flowed together to create a culture of thinking and which help us understand the means by which we can make thinking explicit in the classroom: expectations of the class group's learning, opportunities for realizing these expectations, thinking time (in class, in groups and in other settings), modelling (by the teacher), the language of thinking (conditional, recognizing possibilities, alternatives and perspectives), the physical environment, interactions and thinking routines.

Future research should explore in greater depth the key elements which guarantee the creation of learning contexts, from the standpoint of a holistic interpretation of relevant learning (Perez Gómez, 2008), reflective thinking in the university (Brockbank, McGill, \& Beech, 2002) and deep, effective thinking in the classroom (Perkins, 2008). The quality of such thinking depends on the provision of spaces for discussion, interaction and reflection on the teaching-learning process: "effective thinking refers to the competent and strategic application of thinking skills and productive habits of mind enabling us to carry out premeditated thought acts, such as taking decisions, arguing a case and other analytical, creative or critical actions" (Swartz, Costa, Beyer, Reagan, \& Kallick, 2013, p. 15).

\section{Funding}

This study was undertaken under the aegis of the REDICE-14 project: 'Reflectivity and interdisciplinarity in quality education: learning-based teaching,' coordinated by Marta Sabariego and financed by the Educational Sciences Institute at University of Barcelona. This is a joint university project comprising five degrees and one master's module at the University of Barcelona and the Autonomous University of Barcelona.

\section{References}

Afshar, H. S., \& Rahimi, M. (2016). Reflective thinking, emotional intelligence, and speakingability of EFL learners: Is there a relation? Thinking Skills \& Creativity, 19, 97-111. http://doi.org/10.1016/j.tsc.2015.10.005

Alliaud, A., \& Suárez, D. H. (2011). El saber de la experiencia. Narrativa, investigación y formación docente. Buenos Aires: CLASCO.

Anijovich, R., Cappeletti, G., Mora, S., \& Sabelli, M. (2009). Transitar la formación pedagógica. Dispositivos y Estrategias. Buenos Aires: Paidós.

Avalos, B. (2007). El desarrollo profesional continúo de los docentes: lo que nos dice la experiencia internacional y de la región latinoamericana. Pensamiento Educativo, Vol. 41, no 2, 2007. pp. 77-99.

Bain, J. D., Ballantyne, R., Mills, C., \& Lester, N. C. (2002). Reflecting on practice: Student "teachers" perspectives. Flaxton: Post Pressed.

Barton, K., \& McCully, A. (2007). Teaching controversial issues... where controversial issues really matter. Teaching History, 127, 13-19.

Bird, T. (1997). El portafolios del profesor: un ensayo sobre las posibilidades. In J. Millman \& D. Hammond (Eds.), Manual para la evaluación del profesorado (pp. 332-351). Madrid: La Muralla. 
Boekaerts, M., \& Cascallar, E. (2006). How far have we moved toward the integration of theory and practice in selfregulation?. Educational Psychology Review, 18(3), 199-210

Bourner, T., \& Flowers, S. (1997). Teaching and Learning Methods in Higher Education: A Glimpse of the Future. Reflections On Higher Education, 9, 77-102.

Brockbank, A., McGill, I., \& Beech, N. (2002). Reflective Learning in Practice. Hants, England: Gower Publishing.

Campbell, D. T., \& Stanley, J. C. (1966). Experimental and quasi-experimental designs for research. Chicago, IL: Rand-McNally.

Contreras, P. (2011). Experiencia, escritura y deliberación: explorando caminos de libertad en la formación didáctica del profesorado. In A. Alliaud \& D. H. Suárez (Eds.), El saber de la experiencia. Narrativa, investigación y formación docente (pp. 21-60). Buenos Aires: CLASCO.

Cortés-Nieto, J. de P., Londoño-Toro, B., Luna-de-Aliaga, B. E., Palacios-Sanabria, M. T., \& TorresVillareal, M. L. (2008). Investigación formativa y nuevas propuestas pedagógicas en las Facultades de Derecho. Caso: Facultad de Jurisprudencia de la Universidad del Rosario. Studiositas, 3(1), 28-33.

Cowan, J. (2014). Noteworthy matters for attention in reflective journal writing. Active Learning in Higher Education, 15(1), 53-64.

Davies, J. L. (1998). The Shift from Teaching to Learning: Staff Recruitment and Careers Development Policies for the Universities of the Twenty-First Century. Higher Education in Europe, 23(3), 307-316. http://doi.org/10.1080/0379772980230302

De Miguel, M. (2006). Metodologías de enseñanza y aprendizaje para el desarrollo de competencias. Orientaciones para el profesorado universitario ante el espacio europeo de educación superior. Madrid: Alianza

Dewey, J. (1933). How we think. Buffalo, NY: Prometheus Books.

Dole, S. F. (2017). Creating Cultures of Thinking: The 8 Forces We Must Master to Truly Transform Our Schools. Interdisciplinary Journal of Problem-Based Learning, 11(2).

Dwyer, C. P., Hogan, M. J., \& Stewart, I. (2014). An integrated critical thinking framework for the 21st century. Thinking Skills \& Creativity, 12, 43-52.

Fabregat, J., Guardia, L., \& Forés, A. (2016). La perspectiva del profesorado respecto a la evaluación favorecedora del desarrollo de competencias. In E. Cano \& M. Fernández (Eds.), Evaluación por competencias: la perspectiva de las primeras promociones de graduados en el EEES (pp. 67-80). Barcelona: Octaedro-ICE UB.

Fullana, J., Pallisera, M., Colomer, J., Fernández, R., \& Pérez, M. (2013). Metodologías de enseñanza y aprendizaje reflexivos en la universidad. Una investigación centrada en la percepción de estudiantes de grado de la Universidad de Girona. Revista de Investigación En Educación, 11(2), 60-76.

Fwu, B.-J., Chen, S.-W., Chih-Fen, W., \& Wang, H.-H. (2018). I believe; therefore, I work harder: The significance of reflective thinking on effort-making in academic failure in a Confucianheritage cultural context. Thinking Skills and Creativity. http://doi.org/10.1016/j.tsc.2018.01.004 
Gaitán, C. (2007). Paulo Freire: una pedagogía del diá. In O. Parra de Marroquín (Ed.), Diálogos con Freire para una pedagogía universitaria (pp. 17-29). Bogotá: Pontificia Universidad Javeriana.

García Fanlo, L. (2011). ¿Qué es un dispositivo?: Foucault, Deleuze, Agamben. A Parte Rei. Revista de Filosofía, 74, 1-8.

Gardner, H. (1991). La mente no escolarizada. Barcelona: Paidós.

González-Moreno, C. X. (2012). Formación del pensamiento reflexivo en estudiantes universitarios. Magis, Revista Internacional de Investigación En Educación, 4(9), 595-617.

Grossman, R. (2008). Structures for facilitating student reflection. College Teaching, 57(1), 1522.

Halpern, D. F. (2003). Thought and knowledge: An introduction to critical thinking (4th ed.). New Jersey: Laurence Erlbaum Associates.

Hmelo-Silver, C. E. (2004). Problem-based learning: What and how do students learn? Educational Psychology Review, 16(3), 235-266. http://doi.org/1040-726X/04/09000235/0

Holmes, J., \& Clizbe, E. (1997). Facing the 21st century. Business Education Forum, 52(1), 3335.

Hua, L. (2008). Assessing EFL teachers' reflective thinking: A case study of two in-service secondary teachers. Trends in Applied Sciences Research, 3(1), 36-44. http://doi.org/10.3923/tasr.2008.36.44

Ion, G., Silva, P., \& Cano, E. (2013). El feedback y el feedforward en la evaluación de las competencias de estudiantes universitarios. Revista de Curriculum Y Formación Profesorado, 17(2), 283-301.

Korthagen, F. (2010). La práctica, la teoría y la persona en la formación del Profesorado. Revista Interuniversitaria del Profesorado, 68, 83-101L.

Koszalka, T. A., Song, H.-D., \& Grabowski, B. (2002). Examining Learning Environmental Design Issues for Prompting Reflective Thinking in Web-Enhanced PBL. In Factors that Prompt Reflective Thinking (pp. 1-11). New Orleans, Louisiana: American Educational Research Association.

Mann, K., Gordon, J., \& MacLeod, A. (2009). Reflection and reflective practice in health professions education: a systematic review. Advances in Health Sciences Education, 14(4), 595-621. http://doi.org/10.1007/s10459-007-9090-2

Martínez Fernández, J. (2002). Aprender: necesaria unión entre el querer, el saber y el poder. Revista de Pedagogía, 23(68), 477-494.

McGarr, O., \& Moody, J. (2010). Scaffolding or stifling? The influence of journal requirements on students' engagement in reflective practice. Reflective Practice, 11(5), 579-591. http://doi.org/http://dx.doi.org/10.1080/14623943.2010.516968

Medina, J. L., Jarauta, B., \& Imbernón, F. (2010). L'ensenyament reflexiu a l'educació superior. Barcelona: Octaedro.

Mezirow, J. (2006). An overview of transformative learning. In P. Sutherland \& J. Crowther (Eds.), Lifelong learning. London: Routledge. 
National Academy of Sciences. (2005). National Academy of Engineering Institute of Medicine Rising above the gathering storm: Energising and employing America for a brighter economic future. Washington, DC.

Newton, D. P. (2013). Moods, emotions and creative thinking: A framework for teaching. Thinking Skills and Creativity, 8, 34-44. http://doi.org/10.1016/j.tsc.2012.05.006

Nocetti, A. \& Medina, J.L. (2018). Teacher reflection and the conditions that trigger it in future teachers during their practicums. Espacios, 39 (15). http://www.revistaespacios.com/a18v39n15/18391502.html.

Paniagua, A., \& Instance, D. (2018). Teachers as Designers of Learning Environments: The Importance of Innovative Pedagogies. Paris: OECD.

Parra, C. (2004). Apuntes sobre la investigación formativa. Educación Y Educadores, 7, 57-78.

Pérez-Burriel, M. (2010). La evaluación de la actividad reflexiva a partir del portafolio del estudiante. Revista de Enseñanza de La Psicología: Teoría Y Experiencia, 6(1), 1-12.

Perez Gómez, A. I. (2008). ¿Competencias o pensamiento práctico? La construcción de los significados de representación y de acción. In J. Gimeno-Sacristán (Ed.), Educar por competencias, ¿qué hay de nuevo? (pp. 59-102). Madrid: Morata.

Perkins, D. (2008). La escuela inteligente: Del adiestramiento de la memoria a la educación de la mente. Barcelona: Gedisa.

Perrenoud, P. (2004). Desarrollar la práctica Reflexiva en el oficio de enseñar. Barcelona: Graó.

Phan, H. P. (2008). Metas de logro, el entorno del aula, y el pensamiento reflexivo: un marco conceptual. Revista Electrónica de Investigación Psicoeducativa, 16(6), 571-602.

Plano Clark, V. L., \& Creswell, J. W. (2008). The Mixed Methods Reader. Thousand Oaks, New Delhi, London, \& Far East Square: Sage Publications.

Poblete, M., \& Villa, A. (2007). Aprendizaje Basado en Competencias. Una propuesta para la evaluación de competencias genéricas. Bilbao: Mensajero.

Quintanar, L. (2001). La formación de las funciones psicológicas durante el desarrollo del niño. México: Universidad Autónoma de Tlaxcala.

Ritchhart, R; Church, M y Morrison, K. (2014). Hacer visible el pensamiento: Cómo promover el compromiso, la comprensión y la autonomía de los estudiantes. Barcelona: Paidós.

Ritchhart, R. (2015). Creating Cultures of Thinking: The 8 Forces We Must Master to Truly Transform Our Schools. San Francisco, CA: Jossey-Bass.

Rodríguez, J. L., \& Londoño, G. M. (2009). Los relatos digitales y su interés educativo. Educação, Formação Y Tecnologias, 2(1), 5-18.

Romero, L. (2007). Pensamiento reflexivo: una aproximación inicial en el ámbito de la formación de fonoaudiólogos. Revista Chilena de Fonoaudiología, 8(1), 7-14.

Ryan, M. (2013). The pedagogical balancing act: teaching reflection in higher education. Teaching in Higher Education, 18(2), 144-151. http://doi.org/10.1080/13562517.2012.694104

Sabariego, M. (Coord. . (2014). El valor de la recerca formativa per a la innovació docent i el desenvolupament competencial (2012PID-UB/117). Barcelona. 
Schön, D. (1983). The reflective practitioner. How professionals think in action. New York: Basic Books.

Seldin, P., Miller, E., \& Seldin, C. (2010). The teaching Portfolio. A Practical Guide to Improved Performance and Promotion/tenure Decisions. San Francisco, CA: Jossey Bass.

Solovieva, Y., \& Quintanar, L. (2004). Métodos de intervención en la neuropsicología infantil. México: Benemérita Universidad Autónoma de Puebla.

Suárez, D. H. (2011). Narrativas, autobiografías y formación: una presentación y algunos comentarios. Educación Y Pedagogía, 61(23), 11-24.

Swartz, R.; Costa, A.; Beyer, B.; Reagan, R. i Kallick, B. (2013). El aprendizaje basado en el pensamiento. Cómo desarro llar en los alumnos las competencias del siglo XXI. Madrid: SM.

Talizina, N. (2009). La teoría de la actividad aplicada a la enseñanza. México: Benemérita Universidad Autónoma de Puebla.

Tejada, J., \& Ruiz, C. (2016). Evaluación de competencias profesionales en Educación Superior: Retos e implicaciones. Educación XX1, 19(1), 17-38. http://doi.org/10.5944/educXX1.12175

Tishman, Perkins \& Jay. (2006). Un aula para pensar: Aprender y enseñar en una cultura de pensamiento. Buenos Aires: Aique.

Universitat de Barcelona. (2010). Code of good research practices. Barcelona: Agència de Polítiques i de Qualitat de la UB.

Wenger, M., \& Fergunson, C. (2006). A learning Ecology Model for Blended Learning Capabilities from Sun Microsystems. In C. Bonk \& C. Graham (Eds.), The Handbook of Blended Learning. Global Perspectives, Local Designs (pp. 76-91). San Francisco: Pleiffer.

White, H., \& Sabarwal, S. (2014). Quasi-experimental design and methods. Methodological Briefs: Impact Evaluation 8. Florence.

Yuen Lie Lim, L.-A. (2011). A comparison of students' reflective thinking across different years in a problem-based learning environment. Instructional Science, 39(2), 171-188. http://doi.org/10.1007/s11251-009-9123-8

Zabalza, M. A. (2000). Estrategias didácticas orientadas al aprendizaje. Revista Española de Pedagogía, 58(217), 459-490.

Zabalza, M. A. (2004). Diarios de clase. Un instrumento de investigación y desarrollo profesional. Madrid: Narcea.

Zubizarreta, J. (2009). The Learning Portfolio. Reflective Practice for Improving Student Learning. San Francisco, CA: Jossey Bass. 